\title{
A STUDY OF SEX, AGE, AND REGIONAL DIFFERENCES IN THE ADVANTAGE OF RURAL OVER URBAN MORTALITY
}

\author{
BY \\ W. J. MARTIN \\ Medical Research Council Statistical Research Unit, London School of Hygiene and Tropical Medicine
}

One of the characteristics of mortality in England and Wales is that the ratio of the death rate in the rural areas to that of the country as a whole is proportionately lower for males than for females. This phenomenon was apparent at each age group above 15 years of age up to 1931 . Since 1931 the death rate has fallen considerably, particularly at ages under 45 years where the death rate is now one half of the value of 1931 or less. The purpose of this note is to inquire how the fall in the death rate has affected the relative advantage of rural over urban areas, and in particular whether differences between the sexes in the amount of this advantage vary from one region of the country to another. The method of comparison used is to apply the death rate in males for the whole country, in quinquennial age groups up to age 84 with one group aged 85 and over, for the triennial period for which the census is the middle year, to the rural male population at corresponding ages. The sum of the series gives the number of expected deaths; the actual deaths in the triennium are divided by the expected deaths to give a ratio. This ratio is a measure of the advantage of the country over the towns, the smaller it is the greater the advantage to rural areas. A similar procedure is carried out for females. The results for the last three census periods, by geographical regions, are shown in Table $I$.

Table I shows that the advantage of the mortality in rural over urban areas is greater in males than in females in all three triennial periods. For all rural areas combined, the deaths in males were 19,15 , and 13 per cent. lower than the number expected on the basis of the mortality of the whole country, while the deaths in females were 12,8 , and 7 per cent. lower. The increase in the ratio of actual to expected deaths in the past 20 years is quite small for both sexes. It is, perhaps, a little surprising to find that the rural death rate has declined at almost the same rate as that of the whole country. Since the comparative mortality index has fallen by one quarter during the period, it might have been
TABLE I

DEATHS FROM ALL CAUSES IN RURAL DISTRICTS BY SEX

Actual deaths/Expected deaths

\begin{tabular}{|c|c|c|c|c|c|c|c|}
\hline \multicolumn{2}{|c|}{ Years } & \multicolumn{2}{|c|}{$1920-22$} & \multicolumn{2}{|c|}{$1930-32$} & \multicolumn{2}{|c|}{$1950-52$} \\
\hline Sex & & Male & $\begin{array}{l}\text { Fe- } \\
\text { male }\end{array}$ & Male & $\begin{array}{c}\text { Fe- } \\
\text { male }\end{array}$ & Male & $\begin{array}{c}\text { Fe- } \\
\text { male }\end{array}$ \\
\hline \multirow[t]{2}{*}{ Area } & 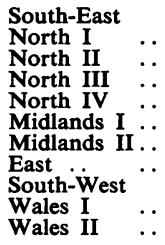 & $\begin{array}{l}0.72 \\
1.02 \\
0.81 \\
0.98 \\
0.86 \\
0.83 \\
0.81 \\
0.73 \\
0.77 \\
0.94 \\
0.93\end{array}$ & $\begin{array}{l}0.76 \\
1.17 \\
0.88 \\
1.04 \\
0.94 \\
0.85 \\
0.90 \\
0.82 \\
0.83 \\
1.06 \\
1.05\end{array}$ & $\begin{array}{l}0.78 \\
1.00 \\
0.84 \\
0.96 \\
0.88 \\
0.86 \\
0.86 \\
0.77 \\
0.84 \\
1.02 \\
0.97\end{array}$ & $\begin{array}{l}0.81 \\
1 \cdot 18 \\
0.96 \\
1.09 \\
0.96 \\
0.91 \\
0.94 \\
0.87 \\
0.88 \\
1 \cdot 13 \\
1 \cdot 09\end{array}$ & $\begin{array}{l}0.79 \\
1.01 \\
0.90 \\
0.96 \\
0.92 \\
0.89 \\
0.89 \\
0.81 \\
0.86 \\
1.04 \\
1.00\end{array}$ & $\begin{array}{l}0.81 \\
1.14 \\
0.99 \\
1.05 \\
0.99 \\
0.93 \\
0.97 \\
0.92 \\
0.91 \\
1.08 \\
1.07\end{array}$ \\
\hline & $\begin{array}{c}\text { England and } \\
\text { Wales }\end{array}$ & 0.81 & 0.88 & 0.85 & 0.92 & 0.87 & 0.93 \\
\hline
\end{tabular}

expected that a relatively greater improvement would have been made in the urban areas where the death rates were larger. In each region and in each triennium the advantage to the males in rural areas was greater than that to the females. In 1950-52 the males had lost a little of the advantage they had in 1930-32, except in North III where it was unaltered. In 1950-52, in males, the observed deaths in North I and Wales I were greater than the expected deaths based on the experience of the whole country. The greatest advantage to rural male mortality was in the South-East, East, and South-West, and the least was in Wales I, North I, Wales II, North III, and North IV. In 1930-32 in four regions, North I, North III, Wales I, and Wales II, the actual deaths in females were 9 to 18 per cent. larger than the expected deaths. In 1950-52, the deaths in females in these regions were still above expectation, but the excess had fallen in each region and was only from 5 to 14 per cent. larger. In other regions the advantage to the females in rural areas was less in 1950-52 than in 1930-32. The relative positions of the regions in order of the advantage of rural mortality were similar in 1930-32 and 1950-52 for both males and females. 
Table II shows the ratio of actual to expected deaths by age. In the first two triennia, the rural mortality was lower than that in the whole country for each sex and age group, except for females aged 15-24 in 1920-22 when it was the same. In 1920-22 and 1930-32 the male advantage was larger than that for females at every age over 14 years, but in 1950-52 it was not until age 45 that the males showed this superiority. In 1950-52 the male deaths at ages $5-14,15-24$, and 25-34 exceeded the number expected. The actual deaths numbered $1,177,2,574$, and 3,043 respectively, compared with $1,110,2,308$, and 2,822 expected deaths, giving an excess of 67 , 266 , and 221. The excess of deaths was mainly due to violence, and at ages 5-14 the observed number of violent deaths was 431 compared with 384 expected. At ages 15-24, the number of violent deaths was 1,467 compared with 989 expected. Unfortunately in the rural areas deaths are not tabulated by causes for ages $25-34$, but for ages $25-44$ deaths from violence numbered 2,194 against 1,597 expected. In males the greatest advantage to the rural areas occurred at ages 45-54 in 1920-22 and 1930-32, but at ages 55-64 in 1950-52. In females the greatest advantage to the rural areas occurred at ages $0-4$ in 1920-22 and 1930-32, but at ages 25-34 in 1950-52.

TABLE II

DEATHS FROM ALL CAUSES IN RURAL DISTRICTS OF ENGLAND AND WALES, BY AGE AND SEX Actual deaths/Expected deaths

\begin{tabular}{|c|c|c|c|c|c|c|c|}
\hline \multirow{2}{*}{$\frac{\text { Years }}{\text { Sex }}$} & & \multicolumn{2}{|c|}{$1920-22$} & \multicolumn{2}{|c|}{$1930-32$} & \multicolumn{2}{|c|}{$1950-52$} \\
\hline & & Male & $\underset{\text { male }}{\text { Fe- }}$ & Male & $\underset{\text { male }}{\mathrm{Fe}}$ & Male & $\begin{array}{c}\text { Fe- } \\
\text { male }\end{array}$ \\
\hline $\begin{array}{c}\text { Age } \\
\text { Group } \\
\text { (yrs) }\end{array}$ & $\begin{array}{c}0-4 \\
5-14 \\
15-24 \\
25-34 \\
35-44 \\
45-54 \\
55-64 \\
65-74 \\
75 \text { and over }\end{array}$ & $\begin{array}{l}0 \cdot 76 \\
0 \cdot 83 \\
0 \cdot 84 \\
0 \cdot 85 \\
0 \cdot 76 \\
0 \cdot 72 \\
0 \cdot 76 \\
0 \cdot 82 \\
0 \cdot 93\end{array}$ & $\begin{array}{l}0.75 \\
0.82 \\
1 \cdot 00 \\
0.99 \\
0.91 \\
0.86 \\
0.84 \\
0.88 \\
0.94\end{array}$ & $\begin{array}{l}0.82 \\
0.88 \\
0.92 \\
0.90 \\
0.82 \\
0.76 \\
0.81 \\
0.84 \\
0.93\end{array}$ & $\begin{array}{l}0.82 \\
0.86 \\
0.95 \\
0.98 \\
0.95 \\
0.91 \\
0.91 \\
0.91 \\
0.96\end{array}$ & $\begin{array}{l}0.98 \\
1.06 \\
1.12 \\
1.08 \\
0.90 \\
0.81 \\
0.80 \\
0.82 \\
0.92\end{array}$ & $\begin{array}{l}0.96 \\
1.03 \\
0.97 \\
0.87 \\
0.90 \\
0.92 \\
0.92 \\
0.92 \\
0.93\end{array}$ \\
\hline
\end{tabular}

The distribution of the ratio is shown for 1950-52 by age and region in Table III, where some exceptions are seen to the general picture given in Tables I and II. In females the lowest ratio was that of the South-East region in each age group; this was also true in males except for ages 15-24 and 25-34, in which there was a lower ratio in North $I$, and for ages $65-74$, in which the ratio was lowest in the East. Table I showed that the rural mortality in both sexes in North I and Wales slightly exceeded that of the whole country, and Table III shows that this holds good for almost every individual age group in these regions. The difference between the sexes was largest at ages 25-34. In this age group, six of the eleven regions showed a considerable sex difference, the males having a ratio from 0.24 to 0.36 larger than the female ratio. The smallest sex differences occurred in old age at $75+$.

Table I leaves no doubt that there are real differences between the regions in the relative level of rural mortality, and Table II shows that there are real age differences. These differences are so large that it is unnecessary to apply statistical tests. It is not obvious, however, whether any sex differences exist between the regions and it seemed of interest to test this point. This was done from Table III by ranking the differences between the sexes in each age group. This method automatically eliminates variation due to age.

The results are seen in Table IV, which shows that there are clearly no significant sex differences between the regions.

TABLE IV

RESULTS OF RANKING THE DIFFERENCES BETWEEN THE SEXES IN EACH AGE GROUP

\begin{tabular}{l|c|c|c|c}
\hline Source of Variation & $\begin{array}{c}\text { Sums of } \\
\text { Squares }\end{array}$ & $\begin{array}{c}\text { Degrees of } \\
\text { Freedom }\end{array}$ & $\begin{array}{c}\text { Mean } \\
\text { Square }\end{array}$ & $\begin{array}{c}\text { Variance } \\
\text { Ratio }\end{array}$ \\
\hline $\begin{array}{l}\text { Between Regions } \\
\text { Within Regions }\end{array}$ & $\begin{array}{c}99 \cdot 33 \\
890.66\end{array}$ & $\begin{array}{c}10 \\
88\end{array}$ & $\begin{array}{r}9.93 \\
10 \cdot 12\end{array}$ & 0.98 \\
\hline Total .. .. & 990 & 98 & & \\
\hline
\end{tabular}

TABLE III

DEATHS FROM ALL CAUSES IN RURAL DISTRICTS IN 1950-52, BY AGE, REGION, AND SEX Actual deaths/Expected deaths

\begin{tabular}{|c|c|c|c|c|c|c|c|c|c|c|c|c|c|c|c|c|c|c|c|}
\hline \multicolumn{2}{|c|}{ Age Group (yrs) } & \multicolumn{2}{|c|}{$0-4$} & \multicolumn{2}{|c|}{$5-14$} & \multicolumn{2}{|c|}{$15-24$} & \multicolumn{2}{|c|}{$25-34$} & \multicolumn{2}{|c|}{$35-44$} & \multicolumn{2}{|c|}{$45-54$} & \multicolumn{2}{|c|}{$55-64$} & \multicolumn{2}{|c|}{$65-74$} & \multicolumn{2}{|c|}{$75+$} \\
\hline Sex & & Male & $\underset{\text { male }}{\text { Fe- }}$ & Male & $\begin{array}{c}\text { Fe- } \\
\text { male }\end{array}$ & Male & $\underset{\text { male }}{\mathrm{Fe}}$ & Male & $\underset{\text { male }}{\text { Fe- }}$ & Male & $\begin{array}{c}\text { Fe- } \\
\text { male }\end{array}$ & Male & $\begin{array}{c}\text { Fe- } \\
\text { male }\end{array}$ & Male & $\begin{array}{c}\text { Fe- } \\
\text { male }\end{array}$ & Male & $\underset{\text { male }}{\text { Fe- }}$ & Male & $\begin{array}{c}\mathrm{Fe}- \\
\text { male }\end{array}$ \\
\hline Region & $\begin{array}{l}\text { South East } \\
\text { North I } \\
\text { North II } \\
\text { North III } \\
\text { North IV } \\
\text { Midllands I } \\
\text { Midlands II } \\
\text { East } \\
\text { South-West } \\
\text { Wales I } \\
\text { Wales II }\end{array}$ & $\begin{array}{l}0 \cdot 79 \\
1 \cdot 35 \\
1 \cdot 11 \\
1 \cdot 19 \\
1 \cdot 07 \\
0.98 \\
0.95 \\
0.98 \\
0 \cdot 88 \\
1 \cdot 19 \\
1 \cdot 34\end{array}$ & $\begin{array}{l}0.78 \\
1 \cdot 20 \\
1.12 \\
1.07 \\
0.93 \\
0.97 \\
0.93 \\
1.03 \\
0.90 \\
1 \cdot 17 \\
1 \cdot 32\end{array}$ & $\begin{array}{l}0.96 \\
1.30 \\
0.98 \\
1 \cdot 12 \\
0.99 \\
1.04 \\
1.01 \\
1 \cdot 19 \\
1.00 \\
1 \cdot 20 \\
1 \cdot 30\end{array}$ & $\begin{array}{l}0 \cdot 95 \\
1 \cdot 16 \\
1 \cdot 13 \\
0 \cdot 77 \\
1 \cdot 16 \\
1 \cdot 11 \\
1 \cdot 07 \\
0 \cdot 88 \\
1 \cdot 08 \\
1 \cdot 27 \\
1 \cdot 19\end{array}$ & $\begin{array}{l}1 \cdot 00 \\
1 \cdot 46 \\
1 \cdot 24 \\
1 \cdot 01 \\
0 \cdot 89 \\
1 \cdot 18 \\
1 \cdot 07 \\
1 \cdot 26 \\
1 \cdot 05 \\
1 \cdot 12 \\
1 \cdot 29\end{array}$ & $\begin{array}{l}0.81 \\
1.32 \\
1.10 \\
0.98 \\
0.86 \\
0.99 \\
0.98 \\
0.93 \\
0.89 \\
1.16 \\
1.33\end{array}$ & $\begin{array}{l}0.92 \\
1.40 \\
1 \cdot 22 \\
1.09 \\
0.88 \\
1 \cdot 16 \\
1 \cdot 01 \\
1.06 \\
1 \cdot 08 \\
1 \cdot 19 \\
1 \cdot 56\end{array}$ & $\begin{array}{l}0.65 \\
1.16 \\
0.95 \\
0.98 \\
0.94 \\
0.91 \\
0.87 \\
0.87 \\
0.72 \\
1.22 \\
1.25\end{array}$ & $\begin{array}{l}0.78 \\
1.26 \\
0.91 \\
1.03 \\
0.92 \\
0.88 \\
0.88 \\
0.80 \\
0.89 \\
1.07 \\
1 \cdot 30\end{array}$ & $\begin{array}{l}0.79 \\
1.13 \\
1.00 \\
1.05 \\
0.83 \\
0.87 \\
0.95 \\
0.91 \\
0.92 \\
0.99 \\
1.00\end{array}$ & $\begin{array}{l}0.72 \\
1.08 \\
0.86 \\
0.83 \\
0.91 \\
0.77 \\
0.81 \\
0.69 \\
0.78 \\
1.02 \\
0.98\end{array}$ & $\begin{array}{l}0.81 \\
1.14 \\
0.92 \\
0.97 \\
0.91 \\
0.90 \\
0.92 \\
0.92 \\
0.94 \\
1.17 \\
1.00\end{array}$ & $\begin{array}{l}0.72 \\
0.93 \\
0.81 \\
0.85 \\
0.88 \\
0.81 \\
0.83 \\
0.69 \\
0.75 \\
1.06 \\
0.92\end{array}$ & $\begin{array}{l}0.82 \\
1.12 \\
0.99 \\
1.01 \\
0.96 \\
0.92 \\
0.94 \\
0.87 \\
0.91 \\
1.04 \\
1.01\end{array}$ & $\begin{array}{l}0.75 \\
0.92 \\
0.82 \\
0.93 \\
0.89 \\
0.81 \\
0.84 \\
0.72 \\
0.80 \\
1.03 \\
0.94\end{array}$ & $\begin{array}{l}0.79 \\
1.18 \\
0.99 \\
1.08 \\
0.99 \\
0.92 \\
0.98 \\
0.91 \\
0.90 \\
1.05 \\
1.06\end{array}$ & $\begin{array}{l}0.85 \\
1.00 \\
0.96 \\
1.01 \\
0.97 \\
0.96 \\
0.95 \\
0.89 \\
0.94 \\
1.00 \\
0.99\end{array}$ & $\begin{array}{l}0.82 \\
1.11 \\
0.99 \\
1.06 \\
1.03 \\
0.93 \\
0.99 \\
0.93 \\
0.92 \\
1.09 \\
1.07\end{array}$ \\
\hline
\end{tabular}


DEATHS IN RURAL DISTRICTS IN Actual deathe

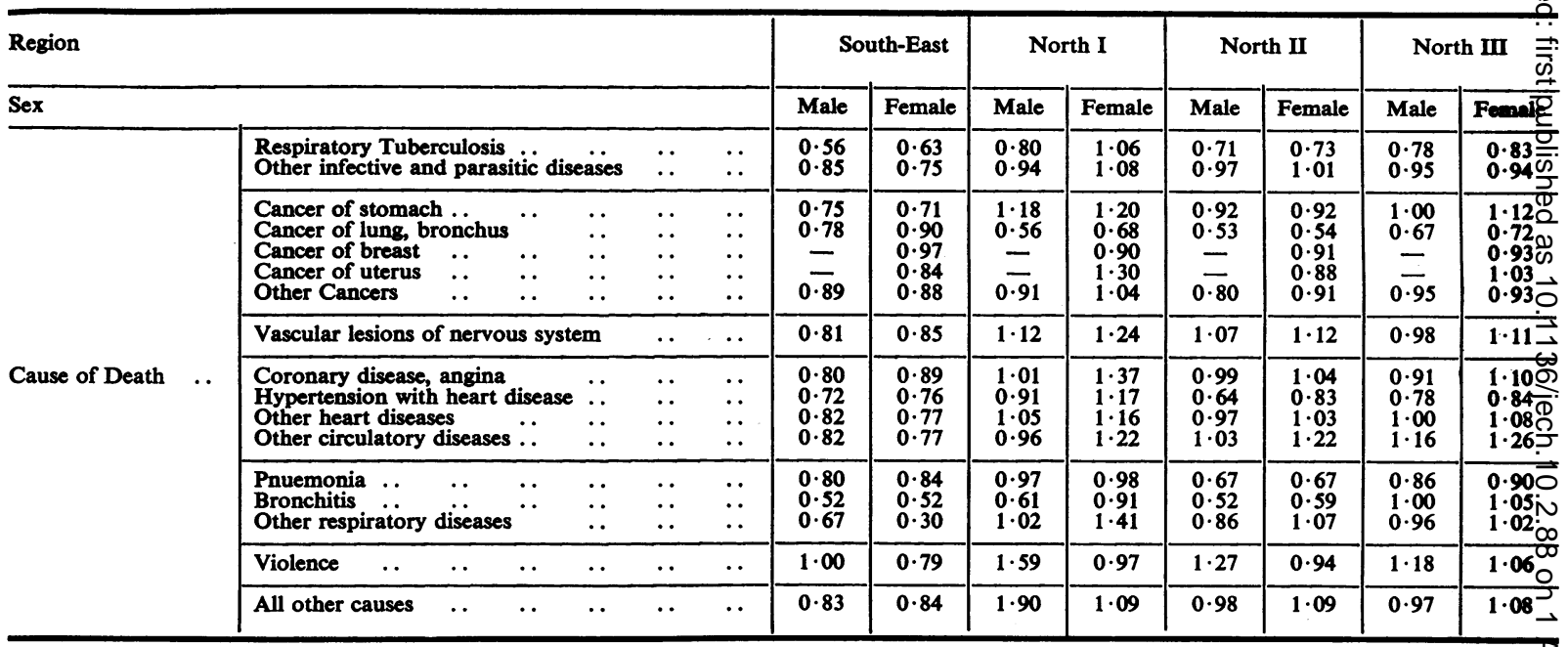

An analysis for the numerically largest causes of death, by sex and region, is given in Table V. For all regions combined, the advantage to rural areas was greater in males than in females for all causes of death except "Other heart diseases", where it was 0.01 higher than the female ratio, and "Violence", where it was 0.28 higher. The other large sex difference was that for "Cancer of the lung"; both sexes showed a considerable rural advantage but, the male ratio was 0.12 below the female.

The advantage to rural areas in mortality from cancer of the lung varied considerably between the regions. In North II, East, and Wales II, the observed deaths in males were only slightly more than half the expected deaths. The South-East region had the largest ratio in males for lung cancer; in contrast, it had the lowest ratio for "All causes of death". In the counties comprising this region, the ratio for lung cancer ranged from 0.68 in East Sussex to 0.98 in Surrey. A ratio of only 0.16 was found in Montgomery and Radnor in Wales II.

The mortality from "Other respiratory diseases" differed considerably between the regions. In males the deaths in the South-East region were two-thirds of the number expected, but in Wales I the actual deaths were nearly three times the number expected. The death rate per 10,000 for males in the rural areas of the counties comprising Wales I was Brecknock $6 \cdot 8$, Carmarthen $14 \cdot 5$, Glamorgan $7 \cdot 7$, and Monmouth $4 \cdot 3$, compared with $3 \cdot 2$ for all rural areas combined.
For all regions combined, the advantage to rural areas in mortality from "Other heart diseases" was slightly greater for females than fo: males. The areas responsible for this exception to the general male superiority were the South-East, Midland I, South-West, and Wales I.

The male deaths from violence substantially exceeded the expected number, except in the SouthEast region where they equalled the expected number. For all rural areas combined, the number of male deaths from violence in the triennial period was 1,127 more than the number expected based on the experience of the whole country. The observed female deaths from violence were 533 fewer than the number expected.

\section{Summary}

The large changes in the death rates during recent years have not affected the relative difference between males and females in the advantage of rural areas over the whole country. The advantage to males was greater than that to females in 1930-32, remained greater in 1950-52, and occurred in every region of the country. The greatest advantage for both sexes was found in the regions of the South-East, East, and South-West, and the least advantage in the regions of North I and Wales.

The age distribution of the ratio in males has undergone some changes during recent years; in 1950-52 the ratio in males between the ages of 5 and 34 was greater than that in females. Furthermore, it was greater than unity, indicating a disadvantage 
V

1950-52 BY CAUSE, REGION, AND SEX

Expected deaths

\begin{tabular}{|c|c|c|c|c|c|c|c|c|c|c|c|c|c|c|c|}
\hline \multicolumn{2}{|c|}{ North IV } & \multicolumn{2}{|c|}{ Midlands I } & \multicolumn{2}{|c|}{ Midlands II } & \multicolumn{2}{|c|}{ East } & \multicolumn{2}{|c|}{ South-West } & \multicolumn{2}{|c|}{ Wales I } & \multicolumn{2}{|c|}{ Wales II } & \multicolumn{2}{|c|}{$\begin{array}{l}\text { England and } \\
\text { Wales }\end{array}$} \\
\hline Male & Female & Male & Female & Male & Female & Male & Female & Male & Female & Male & Female & Male & Female & Male & Female \\
\hline $\begin{array}{l}0.62 \\
0.82\end{array}$ & $\begin{array}{l}0.54 \\
0.87\end{array}$ & $\begin{array}{l}0.65 \\
0.89\end{array}$ & $\begin{array}{l}0.67 \\
1.02\end{array}$ & $\begin{array}{l}0.61 \\
0.81\end{array}$ & $\begin{array}{l}0.88 \\
0.86\end{array}$ & $\begin{array}{l}0.50 \\
0.84 \\
\end{array}$ & $\begin{array}{l}0.74 \\
0.96\end{array}$ & $\begin{array}{l}0.67 \\
0.86\end{array}$ & $\begin{array}{l}0.76 \\
0.93\end{array}$ & $\begin{array}{l}0.89 \\
1.03\end{array}$ & $\begin{array}{l}1 \cdot 29 \\
1 \cdot 10\end{array}$ & $\begin{array}{l}1 \cdot 27 \\
1.03\end{array}$ & $\begin{array}{l}1 \cdot 12 \\
1 \cdot 10\end{array}$ & $\begin{array}{l}0 \cdot 74 \\
0 \cdot 88\end{array}$ & $\begin{array}{l}0.77 \\
0.91\end{array}$ \\
\hline $\begin{array}{c}0.98 \\
0.66 \\
\overline{7} \\
0.86\end{array}$ & $\begin{array}{l}0.94 \\
0.81 \\
0.94 \\
0.96 \\
0.84\end{array}$ & $\begin{array}{c}0.83 \\
0.63 \\
\overline{=} \\
0.89\end{array}$ & $\begin{array}{l}0.95 \\
0.72 \\
0.97 \\
0.81 \\
0.96\end{array}$ & $\begin{array}{c}0.83 \\
0.66 \\
= \\
0.89\end{array}$ & $\begin{array}{l}0.89 \\
0.90 \\
0.93 \\
0.81 \\
0.89\end{array}$ & $\begin{array}{c}0.79 \\
0.52 \\
= \\
0.87\end{array}$ & $\begin{array}{l}0.89 \\
0.67 \\
0.90 \\
0.85 \\
1.01\end{array}$ & $\begin{array}{c}0.90 \\
0.57 \\
= \\
0.89\end{array}$ & $\begin{array}{l}0.86 \\
0.69 \\
0.91 \\
0.87 \\
0.92\end{array}$ & $\begin{array}{c}1.24 \\
0.63 \\
\overline{-} \\
0.86\end{array}$ & $\begin{array}{l}1.29 \\
0.54 \\
0.91 \\
0.93 \\
1.03\end{array}$ & $\begin{array}{c}1.36 \\
0.50 \\
\overline{-} \\
0.96\end{array}$ & $\begin{array}{l}1.49 \\
0.60 \\
0.92 \\
0.94 \\
1.06\end{array}$ & $\begin{array}{c}0.89 \\
0.64 \\
\overline{-} \\
0.89\end{array}$ & $\begin{array}{l}0.91 \\
0.76 \\
0.94 \\
0.88 \\
0.93\end{array}$ \\
\hline 0.96 & 1.04 & 0.90 & 0.96 & 0.91 & $1 \cdot 01$ & 0.84 & 0.95 & 0.85 & 0.98 & 0.95 & $1 \cdot 15$ & $1 \cdot 08$ & $1 \cdot 18$ & 0.90 & 0.98 \\
\hline $\begin{array}{l}1.03 \\
0.67 \\
1.09 \\
0.93 \\
\end{array}$ & $\begin{array}{l}0.99 \\
0.76 \\
1.16 \\
0.92\end{array}$ & $\begin{array}{l}0.78 \\
0.76 \\
0.12 \\
0.89\end{array}$ & $\begin{array}{l}0.84 \\
0.75 \\
0.98 \\
0.80\end{array}$ & $\begin{array}{l}0.79 \\
0.83 \\
1.00 \\
1.03\end{array}$ & $\begin{array}{l}0.94 \\
0.85 \\
1.06 \\
1.08\end{array}$ & $\begin{array}{l}0.74 \\
0.65 \\
0.90 \\
0.86\end{array}$ & $\begin{array}{l}0.87 \\
0.75 \\
0.93 \\
0.84\end{array}$ & $\begin{array}{l}0.83 \\
0.70 \\
0.98 \\
0.90\end{array}$ & $\begin{array}{l}0.88 \\
0.77 \\
0.96 \\
0.97\end{array}$ & $\begin{array}{l}0.92 \\
0.86 \\
1.09 \\
1.09\end{array}$ & $\begin{array}{l}0.87 \\
0.90 \\
1.06 \\
1.25\end{array}$ & $\begin{array}{l}0.82 \\
0.84 \\
1.03 \\
0.86\end{array}$ & $\begin{array}{l}0.79 \\
0.91 \\
0.17 \\
0.94\end{array}$ & $\begin{array}{l}0.84 \\
0.74 \\
0.95 \\
0.91\end{array}$ & $\begin{array}{l}0.92 \\
0.80 \\
0.94 \\
0.92\end{array}$ \\
\hline $\begin{array}{l}0.83 \\
0.64 \\
0.94 \\
\end{array}$ & $\begin{array}{l}0.76 \\
0.86 \\
1.30 \\
\end{array}$ & $\begin{array}{l}0.83 \\
0.61 \\
1.05 \\
\end{array}$ & $\begin{array}{l}0.80 \\
0.74 \\
1.15 \\
\end{array}$ & $\begin{array}{l}0.81 \\
0.71 \\
0.91\end{array}$ & $\begin{array}{l}0.78 \\
0.86 \\
0.98\end{array}$ & $\begin{array}{l}0.72 \\
0.48 \\
0.88 \\
\end{array}$ & $\begin{array}{l}0.77 \\
0.66 \\
1.05\end{array}$ & $\begin{array}{l}0.75 \\
0.50 \\
0.89\end{array}$ & $\begin{array}{l}0.84 \\
0.60 \\
0.98\end{array}$ & $\begin{array}{l}0.80 \\
0.94 \\
2 \cdot 80\end{array}$ & $\begin{array}{l}0.78 \\
1.00 \\
1.08\end{array}$ & $\begin{array}{l}0.75 \\
0.74 \\
1.41\end{array}$ & $\begin{array}{l}0.86 \\
0.86 \\
1.58\end{array}$ & $\begin{array}{l}0.79 \\
0.60 \\
0.96\end{array}$ & $\begin{array}{l}0.81 \\
0.69 \\
1.00\end{array}$ \\
\hline $1 \cdot 11$ & 0.79 & $1 \cdot 20$ & 0.95 & $1 \cdot 18$ & 0.93 & $1 \cdot 24$ & 0.92 & 1.06 & 0.74 & $1 \cdot 23$ & 0.98 & $1 \cdot 20$ & 0.92 & $1 \cdot 15$ & 0.87 \\
\hline 0.94 & $1 \cdot 02$ & 0.99 & 1.01 & 0.95 & 0.99 & 0.90 & $1 \cdot 02$ & 0.97 & 0.98 & $1 \cdot 15$ & $1 \cdot 32$ & $1 \cdot 24$ & $1 \cdot 26$ & 0.95 & 0.99 \\
\hline
\end{tabular}

to rural areas as compared with the whole country. This relative change was mainly due to deaths from

TABLE VI

VIOLENT DEATHS AS A PERCENTAGE OF TOTAL DEATHS

\begin{tabular}{|c|c|c|c|c|c|c|c|c|c|}
\hline \multirow{2}{*}{\multicolumn{2}{|c|}{$\frac{\text { Region }}{\underset{\text { (yrs) }}{\text { Age Group }}}$}} & \multicolumn{4}{|c|}{ England and Wales } & \multicolumn{4}{|c|}{ Rural Districts } \\
\hline & & \multicolumn{2}{|c|}{$5-14$} & \multicolumn{2}{|c|}{$15-24$} & \multicolumn{2}{|c|}{$5-14$} & \multicolumn{2}{|c|}{$15-24$} \\
\hline Sex & & Male & $\begin{array}{c}\text { Fe- } \\
\text { male }\end{array}$ & Male & $\underset{\text { male }}{\mathrm{Fe}-}$ & Male & $\begin{array}{l}\text { Fe- } \\
\text { male }\end{array}$ & Male & $\begin{array}{c}\mathrm{Fe}- \\
\text { male }\end{array}$ \\
\hline Years & $\begin{array}{c}1930- \\
32 \\
1950- \\
52\end{array}$ & $\begin{array}{l}16 \cdot 8 \\
34 \cdot 6\end{array}$ & $\begin{array}{r}8.0 \\
18.9\end{array}$ & $\begin{array}{l}22 \cdot 0 \\
43 \cdot 0\end{array}$ & $\begin{array}{r}5.6 \\
10.6\end{array}$ & $\begin{array}{l}18 \cdot 0 \\
36 \cdot 7\end{array}$ & $\begin{array}{r}9.1 \\
19.0\end{array}$ & $\begin{array}{l}31 \cdot 2 \\
57 \cdot 1\end{array}$ & $\begin{array}{r}7 \cdot 8 \\
13 \cdot 3\end{array}$ \\
\hline
\end{tabular}

violence, which had become proportionately more important in the country as compared with the towns and more so in males than in females. Violent deaths as a percentage of total deaths are shown in Table VI.co

In 1950-52 regional differences varied somewhat? with age. For example, at ages 15-24, the ratio for males was greater than that for females except in the two regions of Wales; at ages 25-34, North IV and Wales I were the exceptions.

The advantage to rural areas was greater in males than in females for most causes of death, "Violence" being the chief exception. Very little difference between the sexes was found for "Other heart diseases" and "Other circulatory diseases". 